\title{
Eternity in Early Modern Philosophy
}

\author{
Yitzhak Y. Melamed
}

God cannot be said to enjoy existence, for the existence of God is God himself.

SPInOza, Cogitata Metaphysica (1663)

It has frequently been argued that with the dawn of modernity, philosophers deserted the Boethian notion of eternity. Thus, Stump and Kretzmann write: "In the modern period, with the rejection of the medieval synthesis in theology, the notion of eternity, in the special sense at issue here, was largely abandoned. Hobbes is still aware of it in the Boethian sense 'as a permanent now, but Locke, for example, takes eternity to be just an infinity of temporal duration." These claims, while broadly correct, are still quite misleading. Indeed, during the seventeenth century, an increasing number of philosophers questioned, and later deserted, the Boethian notion of eternity. ${ }^{2}$ In place of it they adopted and advocated either the sempiternal (i.e., eternity as existence

I E. Stump and N. Kretzmann, "Eternity," in Routledge Encyclopedia of Philosophy, ed. Edward Craig (London: Routledge, 1998), vol. 3, 422-427.

2 For a discussion of the Boethian and late-Platonic notion of eternity, see the end of chapter I above. 
in all times) $)^{3}$ or the new Spinozist conception of eternity. ${ }^{4}$ Yet the Boethian notion was still strongly and broadly present in this period, and it could hardly be said that any seventeenth-century philosopher was not "aware" of it. Thus, Abraham Cohen de Herrera (c. 15701635), the major philosophical kabbalist of early seventeenth-century Amsterdam, celebrates the Plotinian/Boethian notion of eternity:

And it should be noted ... that eternity, as Boethius defines it in his Consolation of Philosophy, "is the whole perfect, and simultaneous possession of endless life," and as Plotinus proves in his profound treatise on eternity and time, it is infinite life or duration which, lacking beginning and end, remains entirely united and in oneness and is consequently so stable and fixed that it neither acquires nor loses anything. ... And as the Prince of Tuscan Poets, Torquato Tasso, says in his dialogue the Messenger, eternity does not contain a first or last, a before or after, or elements in sequence or in motion: rather it is united and withdrawn into itself, like a very placid lake that has no ebb or flow, increase or loss of water. ${ }^{5}$

As I will soon show, many seventeenth-century figures hesitated and oscillated between asserting and questioning the very intelligibility of eternity qua tota simul life. Thus, a report on a 1648 conversation between Descartes (1596-1650) and a young theological student, Frans Burman (1628-1679), says that Burman suggested: "But eternity is all at once and once and for all" (Sed aeternitas est simul et semel). ${ }^{6}$ To this Descartes disparagingly replied: "That is impossible to conceive of

3 See Geoffrey Gorham, “Descartes on God's Relation to Time," Religious Studies 44 (2008): 4I 4, and Luca Bianchi, "Abiding Then: Eternity of God and Eternity of the World from Hobbes to the Encyclopédie," in The Medieval Concept of Time: The Scholastic Debate and Its Reception in Early Modern Philosophy, ed. Pasquale Porro (Leiden: Brill, 200I), 453.

4 The epigraph to this chapter is from CM II I (G I/252/7).

5 Abraham Cohen de Herrera, Puerta del Cielo, bk. 5, chap. 4 (Gate of Heaven, trans. Kenneth Krabbenhoft [Leiden: Brill, 2002], I50-15I). For the original text of Torquato Tasso (I544-1595), see Tasso, Prose (Milan: Riccardo Ricciardi, 1959), 44.

6 Suárez, too, cites approvingly the Boethian formula in Suárez, Disputationes metaphysicae 50.3.6. 
[hoc concipi non potest]. It is all at once and once and for all insofar as nothing is never added to or taken away from the nature of God. But it is not all at once and once for all in the sense that it exists at once [simul existit]."7 By the end of the century, Isaac Newton (1642-1727) pronounced that the Boethian notion was plainly unintelligible: "The human race is prone to mystery, and holds nothing quite so holy and perfect as what cannot be understood [quod intelligi non potest]. Yet in the conception of God this is dangerous, and conduces to the rejection of his existence. ... Let them therefore consider whether it is more agreeable to reason that God's eternity should be all at once [totum simul] or that his duration is more correctly designated by the names Jehovah and 'He that was and is and is to come." "Newton's friend Samuel Clarke (1675-1729) quotes sympathetically the Boethian formula in his Demonstration of the Being and Attributes of God (1704),? yet in his sermons he describes it as unintelligible: “Tis worthy of observation, as to the Manner of our conceiving the Eternity of God; that the Scholastic Writers have generally described it to be, not a Real Perpetual Duration, but One Point or Instant comprehending Eternity, and wherein all things are really co-existent at once. But unintelligible Ways of Speaking have (I think) never done any Service to Religion. The

\footnotetext{
7 Descartes' Conversation with Burman, trans. John Cottingham (Oxford: Clarendon Press, 1976), 6 (AT V I 49). For discussion of this passage, see Gorham, "Descartes on God's Relation to Time," 416-417, and Tad M. Schmaltz, Radical Cartesianism: The French Reception of Descartes (Cambridge: Cambridge University Press, 2002), 200-20I. As I shall later show, on another occasion in the very same year, Descartes expressed agreement with the view that God's eternity is tota simul.

8 J. E. McGuire, "Newton on Place, Time and God, An Unpublished Source," British Journal for the History of Science II (1978): 121.

9 Samuel Clarke, A Demonstration of the Being and Attributes of God (and Other Works), ed. Enzio Vailati (Cambridge: Cambridge University Press, 1998), sec. 5, p. 32: "Thus far we can speak intelligibly concerning the eternal duration of the self-existent being, and no atheist can say this is an impossible, absurd, or insufficient account. It is, in the most proper and intelligible sense of the words, to all the purposes of excellency and perfection interminabilis vitae tota simul et perfecta possesio, the entire and perfect possession of an endless life." Clarke then quotes the claims of Gassendi and Tilloston, who harshly criticize the Boethian formula as unintelligible ( 33 n. 26). Enzio Vailati, Leibniz and Clarke: A Study of Their Correspondence (Oxford: Oxford University Press, 1997), 20, considers these quotes as intimating Clarke's rejection of Boethius. I tend to think that Clarke is genuinely ambivalent about the issue in the Demonstration.
} 
true Notion of the Divine Eternity does not consist in making past things still present, and all things future to be already come." ${ }^{10}$ Why did Descartes, Newton, and Clarke think the Boethian (or Plotinian) formula was an unintelligible mystification? The Boethian formula is committed to the simultaneity of God with all times, and to a notion of life, or duration, that is "all at once." But how can duration be all at once? Of course, various magnitudes, for example, infinite extension, can exist all at once. But if by duration one understands a temporal magnitude, the notion of infinite duration existing all at once seems to be just as paradoxical and contradictory as the notion of infinite extension existing completely at one and the same point.

In this chapter I will trace the history of eternity in the early modern period (roughly 1550-1750). Modernity seemed to be the autumn of eternity. The secularization of European culture provided little sustenance to the concept of eternity with its heavy theological baggage. Yet our hero will not leave the stage without an outstanding demonstration of its power and temptation. Indeed, in the two centuries of early modernity, the concept of eternity played important roles in the period's greatest philosophical systems.

The first part of the chapter concentrates on the debate about God's relation to time. While most of the great metaphysicians of the period-Suárez (1548-1617), Spinoza (1632-1677), Malebranche (1638-1715), and Leibniz (1646-1716) - ascribed nontemporal eternity to God, a growing number of philosophers conceived God as existing in time and eternity as having everlasting existence. For Newton, Gassendi (1592-1655), Henry More (1614-1687), Samuel Clarke, Isaac Barrow (1630-1677), and John Locke (1632-1704), God's eternity was simply the fact that he always was, is, and will forever be. In the second part of the chapter I will examine the concept of eternal truth (aeternae veritates or vérités éternelles). Though this concept has a long history, it became far more central in the early modern period with the emergence of the closely related notion of the "Law of Nature" (lex naturae).

Io Clarke, The Works (1738), 4 vols. (New York: Garland, 1978), vol. I, 22. Italics added. 
The third and most extensive part of the chapter will present Spinoza's original understanding of eternity as self-necessitated existence. Various elements of Spinoza's notion of eternity can be traced back to previous philosophers, but the core of his understanding of eternity is original and surprising. For Spinoza, eternity is primarily a modal notion, a unique kind of necessity and necessary existence. The final part of the chapter will address the reception of Spinoza's concept of eternity in the century following his death. Remarkably, Spinoza's notion of eternity was received positively by figures who would otherwise sharply criticize his philosophy. Oddly enough, the great "atheist" of the early modern period turned out to be the philosophical expert on eternity, namely, the very essence of God.

\section{i God, Time, And Eternity in EARly Modern Philosophy}

Attempting to point out communalities and differences between eternity and time, Abraham Cohen Herrera writes: "The infinite, unmoving present is thus like the origin or source of eternity, while the bounded, manifold, ongoing, and successive present is the cause of time. And in our way of understanding both are measures, that is, eternity is the measure of infinite and abiding being, and time is the measure of limited and movable things, except that time measures by diverse and successive repetitions many times over, as if it were counting or numbering, while eternity measures with a single, unmovable, permanence, unified and focused, in one unmoving moment or indivisible instant." 11 Herrera's dense language seems to assign eternity to only one being: "the infinite and abiding being," which he also calls "the First Cause," that is, God. Other early modern philosophers, however, appear to be somewhat less restrictive in terms of the kind of beings that enjoy eternity. Both Descartes and Spinoza consider the essences

II Herrera, Gate of Heaven, bk. 5, chap. 4 (Krabbenhoft trans., p. I5I). Italics added. 
of things-even finite things-eternal. ${ }^{12}$ In the next part of this chapter I will discuss the "eternal truths," and when I come to interrogate Spinoza, I will show that he believed that in some sense even finite things can be adequately conceived "sub species aeternitatis." In a very different manner George Berkeley (1685-1753) too would find an eternal abode for all things. Thus, in his Three Dialogues, Berkeley puts the following claims in the mouth of Philonous (the dialogues' character that represents Berkley's own views): "All objects are eternally known by God, or which is the same thing, have an eternal existence in his mind; but when things before imperceptible to creatures, are by a decree of God, made perceptible to them; then they are said to begin a relative existence, with respect to created minds."13 Another eternity-related question that engaged early modern philosophers was the issue of eternal punishment and reward. ${ }^{14}$ Finally, we should keep in mind that the threat of the unorthodox view of the universe as eternal a parte ante was clearly present, at least at the back of the mind, to most early modern thinkers. Yet, in spite of these reservations, it is clear that for the early modern philosophers, just as for their medieval predecessors, eternity was the kind of existence that belonged primarily to God. If other beings were said to be eternal, either their eternity would be considered as inferior to God's or they would be said to enjoy eternity by participating-in one manner or another-in God's eternity. For this reason, my main focus in this part of the chapter is the elucidation of the nature of God's eternity, that is, eternity in its full sense and complete colors.

Thomas Hobbes's attack on the Boethian notion of divine eternity was part of a more comprehensive assault he launched in the

\footnotetext{
I2 Descartes, Meditations on First Philosophy (Fifth Meditation) (AT VII 64). For Spinoza, see Ethics, part One, definition 8, explanation, and Part One, proposition 17 , scholium (G II/63/18), and CM II I (G I/239/4).

13 George Berkeley, Three Dialogues between Hylas and Pilonous, ed. Jonathan Dancy (Oxford: Oxford University Press, 1998), dialogue 3, p. 133. Italics added.

I 4 See, for example, Nicolas Malebranche, The Search after Truth, trans. Thomas M. Lennon and Paul J. Olscamp (Cambridge: Cambridge University Press, 1997), 326-328 and 389 .
} 
Leviathan (165I) against Scholasticism. In a crucial passage in chapter 27 of Leviathan - titled "Of Darkness from Vain Philosophy of and Fabulous Traditions"-Hobbes writes:

For the meaning of eternity, they will not have it to be an endless succession of time; for then they should not be able to render a reason how God's will and preordaining of things to come should not be before his prescience of the same (as the efficient cause before the effect, or agent before the action), nor of many other their bold opinions concerning the incomprehensible nature of God. But they will teach us, that eternity is the standing still of the present time, a nunc-stans (as the Schools call it), which neither they, nor any else understand, no more than they would a hic-stans for an infinite greatness of place. $^{15}$

At the beginning of this passage Hobbes suggests an interesting diagnosis of the motive for the wide adoption of the Boethian formula among the Scholastics, claiming that the alternative view of divine eternity as everlasting existence faces the serious objection that if time existed before the creation of the world, God's choice to create the world at any specific instant of time would seem to be arbitrary. Before creation there seem to be no events, and thus all instants of precreation time should be uniform. But in a uniform time, there cannot be a reason to act at $t_{1}$ rather than $t_{2}$, since whatever is true about the one must be true about the other. ${ }^{16}$ According to Hobbes, the Scholastics, attempting to avoid the danger of rendering God's actions arbitrary and incomprehensible, succumbed to another form of unintelligible talk by adopting the contradictory formula of "whole perfect, and simultaneous possession of endless life."

Is Hobbes, Leviathan, ed. Edwin Curley (Indianapolis: Hackett, 1994), 46r. My discussion of Hobbes profited much from Luca Bianchi's excellent article "Abiding Then."

16 This kind of argument is most familiar from the Leibniz-Clarke correspondence, though it has a much longer history. See Bianchi, "Abiding Then," 544-545. 
In his 1656 Elements of Philosophy, Hobbes addresses another argument that aims to vindicate the Boethian formula by pointing out a different problem with the understanding of eternity as everlastingness. Notice that the argument begins with a demonstration addressing the everlastingness of the universe and then shifts to the issue of the proper understanding of God's eternity.

For who can commend him that demonstrates thus? "If the world be eternal, then an infinite number of days, or other measures of time, preceded the birth of Abraham. But the birth of Abraham preceded the birth of Isaac; and therefore one infinite is greater than another infinite, or one eternal than another eternal; which," he says, "is absurd." This demonstration is like his, who from this, that the number of even numbers is infinite, would conclude that there are as many even numbers as there are numbers simply, that is to say, the even numbers are as many as all the even and odd together. They, which in this manner take away eternity from the world, do they not by the same means take away eternity from the Creator of the world? From this absurdity therefore they run into another, being forced to call eternity nunc stans, a standing still of the present time, or an abiding now; and, which is much more absurd, to give to the infinite number of numbers the name of unity. But why should eternity be called an abiding now, rather than an abiding then? Wherefore there must either be many eternities, or now and then must signify the same. With such demonstrators as these, that speak in another language, it is impossible to enter into disputation. ${ }^{17}$

The argument Hobbes employs against the preeternity of the world goes back to medieval philosophy and ultimately to John Philoponus. ${ }^{18}$ The core idea of the argument is that assuming the world had already

17 Hobbes, Elements of Philosophy, chap. 26, sec. I, in Hobbes, The English Works of Thomas Hobbes of Malmesbury, in vols., ed. William Molesworth (London: J. Bohn, I839-45), vol. I, 413. I8 See Bianchi, "Abiding Then," 546-547, and Richard Sorabji, Time, Creation, and the Continuum (London: Duckworth, 1983), 210-231. 
endured for an infinite duration of time, we are bound to get entangled in the paradoxes of infinity in which an infinite quantity turns out to be equal to its part (which is also infinite). That the whole is greater than its part was considered one of the most unshakeable truths for medieval and early modern philosophers. ${ }^{19}$ Thus, if the preeternity of the world led necessarily to the violation of this unshakable truth, the assumption of preeternity would seem to be refuted. Hobbes's own contribution to this discussion was the note that this refutation of the preeternity of the world is just as much a refutation of the preeternity of God, that is, of the conception of divine eternity as everlastingness. Here again, Hobbes claims, attempting to avoid one absurdity, the Scholastics uncritically adopted another absurdity: the Boethian concept of divine eternity.

Hobbes's own position on the issue of divine eternity was quite delicate, as he openly admitted that we could not understand the notion of infinity and infinite time. "But the knowledge of what is infinite can never be attained by a finite inquirer. Whatsoever we know that are men, we learn it from our phantasms; and of infinite, whether magnitude or time, there is no phantasm at all; so that it is impossible either for a man or any other creature to have any conception of infinite." 20 Not being able to offer an intelligible alterative to the nunc stans conception of divine eternity, Hobbes's sophisticated polemics against the Scholastics and their adoption of the Boethian formula resulted in no more than an embarrassing stalemate.

I will turn now to Hobbes's great contemporary René Descartes and look closely at his understanding of divine eternity. I have already mentioned Frans Burman's report that in his 1648 conversation with Descartes, Descartes said that the Boethian formula is just "impossible

\footnotetext{
19 Early modern philosophers frequently refer to the proposition that "the whole is greater that its part" as the stock example of a necessary and evident truth. See Descartes to Mesland, May 2, I644 (AT IV IIO); Spinoza, Ethics, part Four, proposition I8, scholium (G II/222/22); and Leibniz, "Primary Truths," in Leibniz, Philosophical Essays, ed. and trans. R. Ariew and D. Garber (Indianapolis: Hackett, 1989), 31 .

20 Hobbes, Elements of Philosophy, chap. 26, sec. I, in Hobbes, English Works, vol. I, 4II-4I2. Italics added.
} 
to conceive of." ${ }^{21}$ In the very same conversation Descartes is also reported as saying: "We can divide God's duration into an infinite number of parts, even though God himself is not therefore divisible." 22 We might thus suspect that Descartes viewed divine eternity as mere everlastingness. Indeed, in the Fifth Meditation we find Descartes writing: "Apart from God, there is nothing else of which I am capable of thinking such that existence belongs to its essence ... and after supposing that one God exists, I plainly see that it is necessary that he has existed from eternity and will abide for eternity [ab aeterno extiterit, \& in aeternum sit mansurus]." 23 The wording of the last sentence of this passage seems to indicate that Descartes indeed conceived divine eternity as everlastingness, but such a conclusion would be premature. In his 1644 Principles of Philosophy he addresses the nature of divine actions. "[God's] understanding and willing does not happen, as in our case, by means of operations that are in a certain sense distinct one from another; we must rather suppose that there is always a single identical and perfectly simple act by means of which he simultaneously understands, wills and accomplishes everything." 24 The Principles passage presents God's actions as simultaneous, that is, as not having duration. This view still leaves open the possibility that God's existence is spread in time. I will turn then to a 1648 letter in which Antoine Arnauld (1612-1694) suggests to Descartes that human thought too is not successive. "The duration of a permanent and highly spiritual thing [rei permanentis \& maxime spiritalis], such as the mind, is not successive but rather all at once [totam simul] (as is certainly the case with the duration of God)." ${ }^{25}$ To this Descartes replies: "Even if no bodies existed, it could still not be said that that the duration of the human mind was entirely simulatenous [tota simul] like the duration of God [quemadmodum duration Dei]; because our thoughts display a

\footnotetext{
21 Descartes' Conversation with Burman, 6 (AT V I49).

22 Descartes' Conversation with Burman, 6 (AT V I49).

23 AT VII 68. Italics added.

24 Descartes, Principles of Philosophy I.23 (AT IXB I 4 | CSM I 20I). Italics added.

25 Arnauld to Descartes, June 3, 1648 (AT V I88).
} 
succession which cannot be found in the divine thoughts." ${ }^{26}$ We have thus two texts of Descartes, both dated 1648: in the letter to Arnauld he affirms that God endures "all at once"; in the conversation with Burman he claims that this very view is unintelligible.

We find a similar oscillation between affirmation and rejection of the Boethian formula in Nicolas Malebranche's Dialogues on Metaphysics and on Religion (1688). Attempting to explain divine immensity, Theodore, the Malebranchian spokesman in the dialogue, suggests the following analogy:

Created extension is to the divine immensity what time is to eternity. All, bodies are extended in the immensity of God, as all times succeed one another in His eternity. God is everything he is without succession in time. In His existence there is neither past nor future; everything is present, immutable, and eternal. ... God created the world, but the volition to create is not past. God will change the world, but the volition to change is not in the future. The will of God which was and will be is an eternal and immutable act whose effects change without there being a change in God. In a word, God was not, He will not be, but He is. We could say that God was in past time; but $\mathrm{He}$ was then everything $\mathrm{He}$ will be in future time. For His existence and duration, if it permitted to use that term, is completely in eternity, and completely in every passing moment of His eternity. Likewise, God is not partly in heaven and partly in earth. He is completely whole in his immensity, and completely in all the bodies which are locally extended in his immensity. ${ }^{27}$

Theodore's explanation of divine eternity is very close to the Boethian formula, as he denies any succession in God and stresses repeatedly that

\footnotetext{
26 Descartes to Arnauld, June 4, I648 (AT V I93| CSM III 355). Italics added. For a helpful discussion of this passage, see Schmaltz, Radical Cartesianism, 85-86 and 199-200.

27 Malebranche, Dialogues on Metaphysics and on Religion, trans. Nicholas Jolley and David Scott (Cambridge: Cambridge University Press, 1997), dialogue 8, p. 132. Italics added.
} 
God exists all at once. Since Theodore is the character representing Malebranche's view, it would seem that Malebranche fully endorsed the Boethian formula. Yet the response Malebranche puts in the mouth of Aristes-the skeptical disciple of Theodore-presses again the charge of unintelligibility or unclarity against the Boethian formula. "It seems to me, Theodore, that you are explaining an obscure thing by means of another which is not very clear." 28 The analogy Theodore draws between divine immensity and divine eternity is not helpful, claims Aristes, since divine eternity (which was supposed to help explain immensity) is unclear in itself. At this point Theodore responds by noting that Aristes granted that God is eternal earlier in the dialogue, and that it is for this reason that he (i.e., Theodore) brought the analogy with immensity. ${ }^{29}$ However, since Aristes never explained what he understood by divine eternity, Theodore's response appears only partly satisfying.

Less we rashly infer that ambivalence was the only attitude toward the Boethian formula among seventeenth-century philosophers, I stress that one can find unhesitant partisans on both sides of the debate. Thus, Father Pierre Gassendi (1592-1655) rejected the Boethian formula in no unclear terms, claiming: "Eternity cannot be understood as anything else than perpetual duration ... inasmuch as it lacks beginning and end," and placing the blame for the blunder of the Boethian formula in Boethius's reading of the Timaeus..$^{30}$ On the other hand, toward the end of the century, Anne Conway (1631-1679), defended the Boethian formula with equal decisive conviction:

The eternity of creatures is nothing other than an infinity of times in which they were and always are and always will be without end.

\footnotetext{
28 Malebranche, Dialogues, dialogue 8, p. 132.

29 Malebranche, Dialogues, dialogue 8, p. 133.

30 Gassendi, Opera Omnia in sex tomos divisa, 6 vols. (Lyon: Laurent Anisson and JeanBaptiste Devenet, 1658); reprinted in facsimile and with an introduction by Tullio Gergory (Stuttgart: Friedrich Frohmann, 1964), vol. 1, p. 225b. The English translation is quoted from Antonia Lolordo, Pierre Gassendiand the Birth of Early Modern Philosophy (Cambridge: Cambridge University Press, 2007), 127. See her helpful discussion there.
} 
Nevertheless, this infinity of time is not equal to the infinite eternity of God since the divine eternity has no times in it and nothing in it can be said to be past or future, but it is always and wholly present.... And the reason for this is obvious because time is nothing but the successive motions or operations of creatures, and if this motion or operation should cease, then time itself would cease and the creatures themselves would end with time. ... And since in God there is no successive motion or operation toward further perfection because he is absolutely perfect, there are no times in God or his eternity. Furthermore, because there are no parts in God, there are also no times in him since all times have parts and are divisible into infinity. ${ }^{31}$

Conway's two fine arguments in defense of Boethius appeared in her posthumously published Principles of the Most Ancient and Modern Philosophy (1690). At this point in time the tide was growing strongly against the Boethian formula. In his Essay Concerning Human Understanding ( 1690 ), John Locke attempted to explain the nature and origin of our idea of eternity. He thus writes: "By being able to repeat such Idea of any length of Time, as of a Minute, a Year, or an Age, as often as we will in our Thoughts, and adding them one to another, without ever coming to the end of such additions, any nearer than we can to the end of number, to which we can always add; we come by the Idea of Eternity, as the future eternal Duration of our Souls, as well as the eternity of that infinite Being which must necessarily have always existed." ${ }^{2}$ For Locke, eternity is nothing but infinite duration. Yet, Locke argues, we have no clear idea of eternity, just we have no clear idea of infinity of any other kind.

\footnotetext{
3I Anne Conway, The Principles of the Most Ancient and Modern Philosophy, ed. Alison P. Coudert and Taylor Corse (Cambridge: Cambridge University Press, 1996), 13-14. For an illuminating discussion of Conway's understanding of eternity, see Christia Mercer, Exploring the Philosophy of Anne Conway, unpublished book manuscript, chap. 4.

32 Locke, Essay concerning Human Understanding 2.14.31 (An Essay Concerning Human Understanding, ed. Peter H. Nidditch [Oxford: Clarendon Press, 1975], 196).
} 
Having frequently in our Mouths the Name Eternity, we are apt to think we have a positive comprehensive Idea of it, which is as much as to say, that there is no part of that Duration which is not clearly contained in our Idea. It is true that he that thinks so may have a very clear Idea of Duration; he may also have a clear Idea of a very great length of Duration; he may also have a clear idea of the comparison of that great one with still a greater: But it not being possible for him to include in his idea of any Duration, let it be as great as it will, the whole extent together of a Duration, where he supposes no end, that part of his Idea, which is still beyond the Bounds of that large Duration, he represents to his own thoughts, is very obscure and undetermined. And hence it is that in Disputes and Reasonings concerning Eternity, or any other Infinite, we are very apt to blunder, and involve ourselves in manifest absurdities. ${ }^{33}$

At the very end of the seventeenth century, Pierre Bayle (1647-1706) seemed to epitomize the growing embracement surrounding the notion of eternity by stating in his celebrated Dictionnaire (1697) that the common Boethian definition of divine eternity "is far more incomprehensible than the dogmas of transubstantiation [beaucoup plus incomprehensible que le dogme de la Transubstantiation]."34

\section{Eternal Truths}

In section 48 of the first part of his Principles of Philosophy (1644), Descartes writes: "All the objects of our perception we regard either as things, or affections of things, or else as eternal truths [aeternas veritates] which have no existence outside our thought." 35 But what are precisely these "eternal truths" that have no existence outside our mind?

\footnotetext{
33 Locke, Essay concerning Human Understanding 2.29.15 (Nidditch ed., p. 369 ).

34 Pierre Bayle, Dictionnaire Historique et Critique, sth ed. (Amsterdam: P. Brunel, 1740), vol. 4, $53 \mathrm{I}$ n. H. See Bianchi, "Abiding Then," 558.

35 Descartes, Principles of Philosophy I.48 (AT VIIIA 22| CSM I 208). Italics added.
} 
After listing the classes of things and their affections, Descartes turns to the category of eternal truths:

\section{It is not possible-or indeed necessary - to give a similar list of eternal} truths.

Everything in the preceding list we regard either as a thing or as a quality or mode of a thing. But when we recognize that it is impossible for anything to come from nothing, the proposition Nothing comes from nothing is regarded not as a really existing thing [res aliqua existens], or even as a mode of a thing, but as an eternal truth which resides within our mind. Such truths are termed common notions or axioms [communis notion sive axioma]. The following are examples of this class: It is impossible for the same thing to be and not to be at the same time; What is done cannot be undone; He who thinks cannot but exist while he thinks; and countless others. It would not be easy to draw up a list of all of them; but nonetheless we cannot fail to know them when the occasion for thinking about them arises, provided that we are not blinded by preconceived opinions. ${ }^{36}$

Earlier in the Principles, Descartes explained that the common notions are notions "from which the mind constructs various proofs; and for as long as it attends to them, it is completely convinced of their truth." 37 It seems thus that the eternal truths are just the most foundational principles of logic, mathematics, and metaphysics. Descartes's characterization of the eternal truths as "residing within our mind," 38 and apparently not requiring the existence of anything (but God, as I will shortly show), places them in contrast to Descartes's understanding of laws of nature (leges naturae), the regularities that God established in

\footnotetext{
36 Descartes, Principles of Philosophy 1.49 (AT VIIIA 23-24| CSM I 209).

37 Descartes, Principles of Philosophy I.I3 (AT VIIIA 9| CSM I 197). See Descartes, Rules for the Direction of the Mind, rule 12 (AT X 419).

38 Descartes, Principles of Philosophy I.49 (AT VIIIA 23 | CSM I 209).
} 
matter. ${ }^{39}$ Still, what is most striking about Descartes's conception of both eternal truths and laws of nature is that he takes both to be freely chosen by God. Thus, in a letter of April I5, 1630, to his friend Father Marin Mersenne (1588-1648), Descartes writes:

The mathematical truths which you call eternal have been laid down by God and depend on him entirely no less than the rest of his creatures. Indeed, to say that these truths are independent of God is to talk of him as if he were Jupiter or Saturn and to subject him to the Styx and Fates. Please do not hesitate to assert and proclaim everywhere that it is God who lays down laws in his kingdom.... It will be said that if God has established these truths he could change them as a king changes his laws. To this the answer is: Yes he can, if his will can change. ${ }^{40}$

These claims must have surprised Mersenne, as the common Scholastic position, as formulated by Aquinas, restricted divine omnipotence to the realm of the logically possible. ${ }^{41}$ When Mersenne asks Descartes by what kind of causality God creates the eternal truth, Descartes does not seem to budge: "You ask me by what kind of causality God established the eternal truths. I reply: by the same kind of causality as he created all things, that is to say, as their efficient and total cause." ${ }^{\text {"42 }}$

39 See Descartes's early work The World [Le monde], chap. 7 (AT XI 37 ).

40 AT I I45-146| CSM III 23. Just a few weeks later, on May 6, 1630, Descartes writes to Mersenne: "If men really understood the sense of their words they could never say without blasphemy that the truth of anything is prior to the knowledge that God has of it" (AT I I 49| CSM III 24). The target of Descartes's criticism seems to be Francisco Suárez's claim that eternal truths "are not true because they are known by God, but rather they are thus known because they are true" (Suárez, Metaphysical Disputation 3I, sec. I2.4O. For an insightful study of Suárez's position that argues that Descartes's view is just an amended version of Suárez, see Amy Karofsky, "Suárez' Doctrine of Eternal Truths," Journal of the History of Philosophy 39 (2001): 46.

4I "God is unable to make opposites exist in the same subject at the same time and in the same respect.... Since the principles of certain sciences-of logic, geometry, and arithmetic for instance-are derived exclusively from the formal principle of things, upon which their essence depends, it follows that God cannot make the contraries of those principles." Aquinas, Summa Contra Gentiles 2.25.12 and I 4. See Anthony Kenny, The God of the Philosophers (Oxford: Clarendon Press, 1979), 17.

42 Descartes to Mersenne, May 27, 1630 (AT I I5I-152). 
The very intelligibility of the claim that God can change the laws of logic was put under close scrutiny by both Descartes's contemporaries and modern scholars. ${ }^{43}$ The issue comes up repeatedly in the Objections and Replies, which Descartes appended to his Meditations (164I). In the Sixth Set of Replies, more than a decade after the 1630 letter to Mersenne, Descartes still insists that God's will is completely indifferent in deciding which eternal truths to create. ${ }^{44}$ Nothing can make God even incline toward one law rather than the other.

If anyone attends to the immeasurable greatness of God he will find it manifestly clear that there can be nothing whatsoever [nihil omnino esse posse] which does not depend on him. This applies not just to everything that subsists, but to all order, every law, and every reason for anything's being true or good [nullamve rationem veri $\&$ boni]. If this were not so, then ... God would not have been completely indifferent with respect to the creation of what he did in fact create. If some reason for something's being good had existed Prior to his preordination, this would have determined God to prefer those things which it was best to do.... Hence we should not suppose that eternal truths "depend on the human intellect or on other existing things"; they depend on God alone, who, as the supreme legislator, has ordained [instituit] them from eternity. ${ }^{45}$

\footnotetext{
43 For a fascinating and highly influential study of this issue, see Harry Frankfurt, "Descartes on the Creation of the Eternal Truths," Philosophical Review 86 (1977): $36-57$. For a recent helpful overview of the current state of the debate, see David Cunning, "Descartes Modal Metaphysics," in The Stanford Encyclopedia of Philosophy, spring 2014 ed., ed. Edward N. Zalta, sec. 3.

44 There is a major tension between Descartes's insistence here on God's complete indifference as condition for divine freedom and his claims in the Fourth Meditation: "In order to be free, there is no need for me to be inclined both ways; on the contrary, the more I incline in one direction-either because I clearly understand that reasons of truth and goodness point that way, or because of a divinely produced disposition of my inmost thoughts-the freer is my choice. Neither divine grace nor natural knowledge ever diminishes freedom; on the contrary, they increase and strengthen it. But the indifference I feel when there is no reason pushing me in one direction rather than another is the lowest grade of freedom; it is evidence not of any perfection of freedom, but rather of a defect in knowledge or a kind of negation." Fourth Meditation (AT VII 57-58| CSM II 40). Italics added. 45 Sixth Set of Replies (AT VII 436). Italics added.
} 
An interesting objection to these bold claims of Descartes was raised by Pierre Gassendi, who argued that Descartes's view of the eternal truths compromises the uniqueness of God's eternity by making created beings - the eternal truths-just as eternal as God. ${ }^{46}$ At this point, one could expect Descartes to resort to the familiar strategy of making created things eternal only in a secondary and inferior sense. ${ }^{47}$ Instead, Descartes seems to bite the bullet and insist that the eternal truths are just as eternal as God himself.

You say that you think it is "very hard" to propose that there is anything immutable and eternal apart from God. You would be right to think this if I was talking about existing things, or if I was proposing something as immutable in the sense that its immutability was independent of God. But just as the poets suppose that the Fates were originally established by Jupiter, but that after they were established he bound himself to abide by them, so I do not think that the essences of things, and the mathematical truths which we can know concerning them, are independent of God. Nevertheless I do think that they are immutable and eternal, since the will and decree of God willed and decreed that they should be so. Whether you think this is hard or easy to accept, it is enough for me that it is true. ${ }^{48}$

Descartes's reply to Gassendi seems to admit that were he speaking of eternal truths as "existing things" (de re existente), Gassendi's objection would be in place. Indeed, at the beginning of my discussion I showed that in Principles I.48, Descartes explicitly refers to eternal truths as

\footnotetext{
46 Fifth Set of Objections (AT VII 319 ).

47 There is some evidence that Descartes considered eternal truths as merely everlasting. See Fifth Set of Replies (AT VII 38I): "Since eternal truths are always the same [eadem semper], it is right to call them immutable and eternal" (AT VII $38 \mathrm{I} \mid$ CSM II 262). See Gorham, "Descartes on God's Relation to Time," 423 , for a discussion of this passage.

48 Fifth Set of Replies (AT VII 380 ol CSM II 26I).
} 
a class distinct from both things and the affections of things. On the other hand in the First Set of Replies Descartes counters Johannes Caterus's claim that "an eternal truth does not require a cause," by insisting that an eternal truth, just like any other idea, "surely needs a cause enabling it to be conceived." ${ }^{\prime 49}$ Thus, eternal truths are not just nothingness that does not require a cause. Just like the Cartesian God, (Cartesian) eternal truths are mental items, and just like God, eternal truths are eternal. For Gassendi, such a situation threatens the uniqueness of God. Of course, Descartes would claim that eternal truths do not exist outside the human mind, while God does. But since God exists outside the human mind as another (infinite) mind, Gassendi could easily reply to Descartes that eternal truths exist outside my mind, in the minds of other people. The main point of Gassendi is that unlike many of his medieval predecessors, Descartes does not locate the eternal truths in God's mind; ${ }^{50}$ rather, he considers them as created beings. Granting full-fledged eternity to a created being may indeed be as a small but crucial step on a path leading to idolatry.

Before I turn to discuss Spinoza's new conception of eternity in the next section, let me briefly point out Spinoza's radical reconceptualization of the notion of eternal truth. Descartes's view of God as legislating-like a king—the eternal truths and the laws of nature was primarily an object of ridicule for Spinoza, who considered such views as gross and childish instances of anthropomorphic thinking. Thus, in the scholium to the third proposition of Part Two of the Ethics, Spinoza writes: "By God's power ordinary people [Vulgus] understand God's free will and his right over all things which are, things which on that account are commonly considered to be contingent. For they say that God has the power of destroying all things and reducing them to nothing. Further, they very often compare God's power

\footnotetext{
49 First Set of Objections (AT VII ${ }_{93} \mid$ CSM II 70). The aim of Caterus's claim was to undermine the Cartesian proof of the existence of God in the Third Meditation. so See Kenny, God of the Philosophers, I5-17, who stresses this point.
} 
with the power of Kings." ${ }^{1}$ In his Theological Political Treatise (1670) Spinoza draws a distinction between eternal truths and laws of nature that is very different from Descartes's (and indeed aims at eradicating Descartes's claim that God freely creates the eternal truths). In the following passage Spinoza explains the process by which a law of nature turns into an eternal truth: "As for the divine natural law whose highest precept we have said is to love God, I have called it a law in the sense in which philosophers apply the word 'law' [legem] to the common rules of nature according to which all things happen. ... Divine commandments seem to us like decrees or enactments only so long as we are ignorant of their cause. Once we know this, they immediately cease to be edicts, and we accept them as eternal truths, not as decrees." 52 In describing natural regularities as laws, we conceive these regularities as expressions of the arbitrary will of the master of the universe. We are confident in the necessity of these regularities, yet being ignorant of their causes and not being able to explain their necessity, we conceive of them as decrees of a most powerful agent. One can see this analysis as Spinoza's attempt to understand the psychological processes that led people like Descartes to view God as freely legislating the laws of nature. In the above passage Spinoza refrains from judging this form of anthropomorphic thinking and only adds that the ignorance (of the causes of natural regularities) that is the ground of the conception of God as legislator is corrigible. Once we learn the causes of natural regularities they no longer appear arbitrary, and thus we no longer conceive of them as laws. Once we fully understand the causal and explanatory ancestries of these regularities we conceive of them as eternal truth. The more we learn the causes of

\footnotetext{
5I Unless otherwise marked, all references to the Ethics, the early works of Spinoza, and Letters I-29 are to Curley's translation: The Collected Works of Spinoza. Vol. r. Edited and translated by Edwin Curley. (Princeton: Princeton University Press, 1985). In references to the other letters of Spinoza I have used Shirley's translation: Spinoza, Complete Works, translated by Samuel Shirley (Indianapolis: Hackett, 2002). I have relied on Gebhardt's critical edition (Spinoza Opera, 4 volumes (Heidelberg: Carl Winter Verlag, 1925)) for the Latin text of Spinoza.

52 Spinoza, Theological Political Treatise, trans. Michael Silverthorne and Jonathan Israel (Cambridge: Cambridge University Press, 2007), chap. 16, n. 34 (G III/264). Italics added.
} 
laws of nature, the closer we are to conceiving them as fully rational and transparent eternal truths.

Throughout the Theological Political Treatise, Spinoza brings several examples of eternal truths that were conceived by various biblical figures as laws or edicts. ${ }^{53}$ I will conclude my brief discussion of eternal truths with a striking passage in which Spinoza points out that even the existence of God - an obvious eternal truth, for Spinoza-could be misconceived as an edict. The occasion for this misconception, according to Spinoza, was none other than God's revelation on Mount Sinai.

It is for the same reason too, namely deficiency of knowledge [defectum cognitionis], that the Ten Commandments were law [lex] only for the Hebrews. Since they did not know [noverant] the existence of God as an eternal truth, i.e., that God exists and that God alone is to be adored, they had to understand it as decrees [legem]. If God had spoken to them as directly without the use of any physical means, they would have perceived this same thing not as an edict [legem] but as an eternal truth. ${ }^{54}$

\section{Spinoza on Eternity}

\section{as Self-Necessitated Existence}

Spinoza's philosophy is as bold and original as it is difficult. ${ }^{55}$ For this reason, I will precede my examination of Spinoza's novel conception of eternity with a brief exposition of the three building blocks of his ontology: substance (substantia), attribute (attributum), and mode

\footnotetext{
53 See, for example, Theological Political Treatise, chap. 4 (G III/63): "Adam perceived that revelation not as an eternal and necessary truth but rather as a ruling, that is, as a convention that gain or loss follows, not from the necessity and nature of the action done, but only from the pleasure and absolute command of the prince. Therefore that revelation was a law and God was a kind of legislator or prince exclusively with respect to Adam, and only because of the deficiency of his knowledge."

54 Spinoza, Theological Political Treatise, chap. 4 (G III/63).

55 This section of the chapter relies partly on my article "Spinoza's Deification of Existence," Oxford Studies in Early Modern Philosophy 6 (2012): 75-104, and my Spinoza's Metaphysics: Substance and Thought (New York: Oxford University Press, 2013), I21-I26.
} 
(modus). ${ }^{56}$ At the opening of part I of the Ethics, Spinoza provides the following definitions for substance, attribute, mode, and God (Spinoza's infinite and unique substance):

Definition 3: By substance I understand what is in itself and is conceived through itself, i.e., that whose concept does not require the concept of another thing, from which it must be formed.

Definition 4: By attribute I understand what the intellect perceives of a substance, as constituting its essence.

Definition 5: By mode I understand the affections of a substance, or that which is in another through which it is also conceived.

Definition 6: By God I understand a being absolutely infinite, i.e., a substance consisting of an infinity of attributes, of which each one expresses an eternal and infinite essence.

Explanation: I say absolutely infinite, not infinite in its own kind; for if something is only infinite in its own kind, we can deny infinite attributes of it $\left[\mathrm{NS}:{ }^{57}\right.$ (i.e., we can conceive infinite attributes which do not pertain to its nature)]; but if something is absolutely infinite, whatever expresses essence and involves no negation pertains to its essence.

Each of these definitions raises numerous interpretative questions and has been a source of many scholarly debates. Still, we can get the gist of Spinoza's understanding of substance and mode by noting that Spinoza defines substance as that which is independent both ontologically ("in itself" [in se est]) and conceptually ("is conceived through itself [per se concipitur]"), while mode is defined as that which is dependent on another both ontologically ("in another" [in

56 For a close study of Spinoza's understanding of these three concepts, see my article "The Building Blocks of Spinoza's Metaphysics: Substance, Attributes, and Modes," in Della Rocca The Oxford Handbook of Spinoza. For a study of the chronological development of Spinoza's understanding of substance and attribute, see my "A Glimpse into Spinoza's Metaphysical Laboratory."

57 "NS" is a reference to the 1677 , Nagelate Schriften, the Dutch translation of Spinoza's works which was published simultaneously with Spinoza's Opera Posthuma, nine months after his death. 
alio est]) and conceptually ("through which it is also conceived" [per quod etiam concipitur].

Both the attributes and the modes are qualities of the substance. However, the attributes are the essential qualities of the substance, while the modes are nonessential qualities of the substance (i.e., qualities that the substance can gain and lose). Since the attributes are the essential qualities of the substance, Spinoza argues that they must share the substance's defining characteristic of being self-conceived (i.e., no attribute can be conceived through another attribute). ${ }^{58}$

Relying on the asymmetric dependence of modes on the substance, Spinoza proves that two substances cannot share the same attribute. ${ }^{59}$ Relying on the definition of substance as an independent being, Spinoza proves that one substance cannot be the cause of another. ${ }^{60}$ These three crucial steps-the self-conceivability of attributes, the fact the substances (if there are any) cannot share an attribute, and that substances are causally isolated-lead Spinoza to the proof that God, a substance of infinitely many attributes, must exist, ${ }^{61}$ and shortly afterward to the demonstration that God is the only possible substance. ${ }^{62}$

Another crucial distinction we should have in mind is between what Spinoza calls Natura naturans and Natura naturata. Here are his explicit definitions of the two: "By Natura naturans we must understand what is in itself and is conceived through itself, or such attributes of substance as express an eternal and infinite essence, i.e. (by $\mathrm{P}_{14} \mathrm{C}_{\mathrm{I}}$ and $\left.\mathrm{P}_{17} \mathrm{C}_{2}\right)$, God, insofar as he is considered as a free cause. But by Natura naturata I understand whatever follows from the necessity of God's nature, or from any of God's attributes, i.e., all the modes of God's attributes insofar as they are considered as things which are in

\footnotetext{
58 See Ethics, Part One, proposition 9, demonstration.

59 See Ethics, Part One, proposition 5, demonstration.

60 See Ethics, Part One, proposition 6, demonstration.

6I See Ethics, Part One, proposition II, demonstration.

62 See Ethics, Part One, proposition I4, demonstration. For an excellent reconstruction of the entire argument (following the steps noted above), see Michael Della Rocca, "Spinoza's Substance Monism," in Spinoza: Metaphysical Themes, ed. Koistinen and Biro (Oxford: Oxford University Press, 2003), II-37.
} 
God, and can neither be nor be conceived without God."63 Roughly speaking, Natura naturans is the realm of the essence of substance, and its infinitely many attributes, while Natura naturata is the realm of the modes, the nonessential qualities that follow from the essence of God, the unique and only substance.

With this cursory overview of the foundation of Spinoza's ontology at hand, I can now approach his understanding of eternity. My discussion will focus primarily on Spinoza's masterwork, the Ethics, though occasionally I will also refer to some of his earlier works and letters.

At the beginning of the climactic conclusion of the Ethics, Spinoza writes: "Eternity is the very essence of God insofar as this involves necessary existence [Aeternitas est ipsa Dei essentia, quatenus haec necessariam involvit existentiam] (by Definition 8 of Part I)." ${ }^{64}$ In this passage Spinoza appeals to the definition of eternity that appears at the opening of the Ethics: "By eternity I understand existence itself, insofar as it is conceived to follow necessarily from the definition alone of the eternal thing [Per aeternitatem intelligo ipsam existentiam, quatenus ex sola rei aeternae definitione necessario sequi concipitur]." 65 To this enigmatic definition, which apparently sins in obvious circularity (by employing the definiendum, "eternity," in the definiens), Spinoza attaches the following explanation: "For such existence, like the essence of a thing, is conceived as an eternal truth, and on that account cannot be explicated by duration or time, even if the duration is conceived to be without beginning or end [Talis enim existentia ut aeterna veritas, sicut rei essentia, concipitur, proptereaque per durationem aut tempus explicari non potest, ${ }^{66}$ tametsi duratio principio

63 See Ethics, Part One, proposition 29, scholium.

64 Ethics, Part Five, proposition 30, demonstration. See Spinoza, Cogitata Metaphysica (=CM) II I (G I/25I/II): "The reasons why Writers have attributed duration to God. The reason why these Writers have erred is threefold: first, because they have attempted to explain eternity without attending to God, as if eternity could be understood without contemplation of the divine essence- or as if it were something beyond the divine essence." Italics added.

65 Ethics, Part One, Definition 8.

66 The recently discovered Vatican manuscript of Spinoza's Ethics has here "nequit" instead of "non potest." See Spinoza, The Vatican Manuscript of Spinoza's "Ethics," ed. Leen Spruit and Pina Totaro (Leiden: Brill, $201 \mathrm{I}), 84$. 
et fine carere concipiatur]. ${ }^{\circ 7}$ In the existing literature there is some debate about Spinoza's understanding of eternity, and of the related issue of mind eternity. Some scholars interpret Spinoza's notion of eternity as mere sempiternity, or everlasting existence, while others consider it atemporal. ${ }^{68}$ Although I have significant reservations about both readings, I find the atemporal interpretation more accurate. I will begin by registering that the primary meaning of aeternitas in Spinoza, as expressed in the official definition of the term in Ethics, part One, Definition 8, is explicitly contrasted with sempiternity or, in Spinoza's words, with "duration [that] is conceived to be without beginning or end." ${ }^{69}$ Indeed, Spinoza stresses several times that "in eternity, there is neither when, nor before, nor after." 70 Similarly, he argues, "we cannot ascribe future existence to God, because existence is of his essence." 71 Spinoza's claim in Ethics, part One, definition 8, explanation, that eternity is existence "conceived as an eternal truth" provides further support for the rejection of the sempiternal reading, since he clearly regards eternal truths as not enduring: "No one will ever say that the essence of a circle or a triangle, insofar as it is an eternal truth, has endured longer now than it had in the time of Adam." 72

67 Ethics, Part One, Definition 8, explanation. See CM II I (G I/252/17-18): "I call this infinite existence eternity, which is to be attributed to God alone, and not to created things, even though its duration should be without beginning or end." Italics added.

68 For the view of Spinoza's eternity as mere sempiternity, see Martha Kneale, "Eternity and Sempiternity," in Spinoza: A Collection of Critical Essays, ed. Marjorie Green (New York: Anchor Books, 1973), 227-224, and Alan Donagan, Spinoza (Chicago: University of Chicago Press, 1988), 107-113. The opposite, timeless reading of mind eternity, is advocated by Diane Steinberg, "Spinoza's Theory of the Eternity of the Mind," Canadian Journal of Philosophy II (198I): 55-65.

69 Even Kneale, who supports the sempiternal interpretation of mind eternity, concedes that the definition of eternity at the opening of the Ethics is not consistent with the sempiternal reading. It is only "by the time he came to write Part V," claims Kneale, that Spinoza changed his view and "was thinking in a more Aristotelian way" ("Eternity and Sempiternity," 238). Against Kneale I would argue that it would be very odd for Spinoza not to revise such a key definition in the Ethics, had he abandoned his original nondurational understanding of eternity.

70 Ethics, Part One, proposition 33, second scholium. See CM I 3 (G I/243/12): "In Eternity there is no when, not before, or after, nor any other affection of time." See CM II I (G I/25I/I). The last sentence is probably the closest Spinoza comes to the Boethian formula.

7I CM II I $(\mathrm{G} \mathrm{I} / 252 / 13)$.

72 CM II I (G I/250/29). 
The definition of eternity at the opening of the Ethics (and its explanation) clearly rules out any conception of eternity as limitless duration, ${ }^{73}$ but we should also pay close attention to the positive content of the definition. The definition not only tells us what eternity is-existence-but also tells what kind of existence it is-"existence itself, insofar as it is conceived to follow necessarily from the definition alone of the eternal thing" - that is, the existence of a thing whose existence follows necessarily from its own essence. ${ }^{74}$ Indeed, in Ethics, part One, proposition 23, scholium, Spinoza relies on his definition of eternity in order to identify eternity with the "necessity of existence" (necessitate existentiae) that each attribute of God is conceived to express: "So if a mode is conceived to exist necessarily and be infinite, [its necessary existence and infinitude] must necessarily be inferred [concludi], or perceived through some attribute of God, insofar as that attribute is conceived to express infinity and necessity of existence, or (what is the same, by D8) eternity [quatenus idem concipitur infinitatem, et necessitatem existentiae, sive (quod per Defin. 8. idem est) aeternitatem exprimere], i.e. (by D6 and Pr9), insofar as it is considered absolutely." 75 On two other occasions in the Ethics, Spinoza uses the phrase "eternity or [sive] necessity." In Ethics, part One, proposition Io, scholium, Spinoza writes: "Nothing in nature is clearer than that each being must be conceived under some attribute, and the more reality, or being [realitatis, aut esse] it has, the more it has attributes which express necessity, or eternity [necessitatem, sive aeternitatem], and infinity." Similarly, Ethics, part Four, proposition 62, demonstration, reads: "Whatever the Mind conceives under the

73 See CM II I (G I/25I/24) for Spinoza's detailed critique of those who consider eternity "a species of duration" and do not distinguish between God's eternity and the (infinite) duration of created things. I will shortly address the issue of the eternity of infinite modes.

74 The "conception of existence" in Ethics, Part One, Definition 8, must be adequate, for otherwise, Spinoza's proof in Ethics, Part one, proposition 19, demonstration-which relies on Definition 8 -would be invalid. Thus, since eternity is existence, adequately conceived to follow from the definition of an eternal being, we may conclude that such existence indeed "follows from the definition alone of the eternal thing."

75 Ethics, Part One, proposition 23, scholium. Italics added. 
guidance of reason, it conceives under the same species of eternity, or necessity [sub eadem aeternitatis, seu necessitatis specie concipit]." Almost always, Spinoza employs the Latin sive to designate equivalent terms, and the occurrences of the term in the above two passages are no exceptions. Thus, we have solid textual evidence showing that for Spinoza there is a very intimate relation between eternity and necessity. Some commentators have suggested that Spinoza identifies eternity with necessity, or necessary existence, ${ }^{76}$ but this qualification is imprecise and insufficient, since for Spinoza the existence of all things is necessary. ${ }^{77}$ What is truly unique to Spinoza's notion of eternity is its being self-necessitated (or necessitated by virtue of its mere essence), whereas all other things are necessary by virtue of causes that are not identical with their essences. ${ }^{78}$ Here is Spinoza's presentation of this crucial distinction: "A thing is called necessary either by reason of its essence or by reason of its cause. For a thing's existence follows necessarily either from its essence and definition or from a given efficient cause [Rei enim alicujus existentia vel ex ipsius essentia, et definitione, vel ex data causa efficiente necessario sequitur]."79 I will look closely at the second sentence of this passage. The notion of existence necessarily following from the definition (and essence) ${ }^{80}$ of a thing should

76 See, for example, Kneale, "Eternity and Sempiternity," 235-238, and B. Leftow, Time and Eternity (Ithaca, NY: Cornell University Press, I99I), 63. Regrettably, these scholars are insensitive to Spinoza's important distinction between different kinds of necessary existence: necessary existence by virtue of one's essence as opposed to necessary existence by virtue of one's cause. See Ethics, Part One, proposition 33, scholium I.

77 See Ethics, Part One, proposition 29, and Ethics, Part One, proposition 33. For an insightful discussion of Spinoza's necessitarianism, see Don Garrett, "Spinoza's Necessitarianism," in God and Nature: Spinoza's Metaphysics, ed. Yirmiyahu Yovel (Leiden: Brill, 1991), 97-118. On the intimate connection between necessity and eternity in al-Kindī and Avicenna, see chapter 2 here.

78 Herrera comes very close to identifying eternity with self-necessitated existence, claiming that what is "necessary by itself is, therefore, eternal." Gate of Heaven, bk. 5, chap. 4 (Krabbenhoft trans., p. 150). For Spinoza's adoption of the Maimonidean interpretation of "ego sum qui sum" (Exodus 3:I4) as indicating God's self-necessitated existence, see my "Deification of Existence," 83-86.

79 Ethics, Part One, proposition 33, scholium r.

80 For Spinoza, an adequate definition must capture the essence of the thing defined. See Tractatus de Intellectus Emendatione [Treatise on the Emendation of the Intellect], section 95. As a result, he frequently treats the two terms as interchangeable. 
be familiar by now: this is just the definition of eternity in Ethics, part One, definition 8. I am coming close to excavating Spinoza's understanding of eternity, but I am not yet there.

At this point it may be interesting to compare Spinoza's and Boethius's views of eternity. While both philosophers reject the conception of eternity as everlastingness, Spinoza, unlike Boethius, defines eternity without employing, or even referring to, the terminology associated with duration and time (such as Boethius's tota simul [all at once]). Only in the explication of his definition of eternity does Spinoza note that eternity cannot be equated with infinite duration, or time. This point is quite significant, since the role of a definition in Spinoza's system is to capture the essence of a thing. ${ }^{81}$ Thus, it seems that for Spinoza, the essence of eternity is captured not by any relation-not even negation - to duration or time. Spinoza seems to be stressing this very point by noting that "eternity can neither be defined by time nor have any relation to time [nec aeternitas tempore definiri, nec ullam ad tempus relationem habere potest]." 82 Instead, he proposes a genuine definition of eternity as a unique kind of modality: selfnecessitated existence. While quite a few of his predecessors associated eternity with necessity in one manner or another, he seems to go far beyond them in completely relocating this notion from the domain of temporality and defining it as a primarily a modal concept. ${ }^{83}$ This new understanding of eternity as self-necessitated existence may also shed light on the circularity in Spinoza's definition of eternity (Ethics, part One, definition 8). Rather than a beginner's error, it seems to be a premeditated move attempting to capture the essential feature of eternity as self-necessitated.

\footnotetext{
81 See Tractatus de Intellectus Emendatione, section 95, and Ep. 9 (G IV/42/30).

82 Ethics, Part Five, proposition 23, scholium. Italics added.

83 Many of Spinoza's predecessors affirmed the identity of essence and existence in God, but they did not see it as constituting God's eternity. According to Gorham ("Descartes on God's Relation to Time," 422-423), Descartes considered this identity compatible with God's being in time, as he seamlessly moved, in the Fifth Meditation, from asserting the identity God's essence and existence to ascribing temporality to God.
} 
Apart from the definition of eternity at the opening of the Ethics, the other key text for understanding Spinoza's concept of eternity is Letter I2, famously known as the "Letter on the Infinite." Spinoza circulated copies of this letter also in his very late period, ${ }^{84}$ and thus it seems to reflect his views during this time as well. In this difficult and intriguing text, Spinoza suggests a threefold distinction between eternity (aeternitas), duration (duratio) and time (tempus). In explaining the distinction between the first two, Spinoza claims, "we conceive the existence of Substance to be entirely different from the existence of Modes. The difference between Eternity and Duration arises from this. ${ }^{85}$ For it is only of Modes that we can explicate [explicare possumus ${ }^{86}$ the existence by Duration. But [we can explicate the existence] of Substance by Eternity, i.e., the infinite enjoyment of existing, or (in bad Latin) of being [infinitam existendi, sive, invitâ latinitate, essendi fruitionem]." ${ }^{87}$ Spinoza's use of the verb explicare in this passage may seem a bit odd. He is not looking here for an explanation of the causes of existence but is suggesting that existence can be explicated, or unfolded, as either duration or eternity. Eternity is the proper explication of the existence of substance, or the thing whose essence and existence are one and the same, while duration is the proper explication of the existence of modes, or things whose existence is distinct from their essence. A similar, though slightly different, distinction appears in a section titled "What Eternity Is; What Duration Is" in Spinoza's early work the Cogitata Metaphysica: "From our earlier division of being into being whose essence involves existence and being whose essence

\footnotetext{
84 See Eps. 80 and $8 \mathrm{r}$.

85 For a detailed discussion of the bifurcation between eternity and duration and its sources, see my Spinoza's Metaphysics, $105-112$.

86 I have altered Curley's translation here, translating explicare as "explicate" instead of "explains." 87 Ep. I2 (G IV/54/16-55/3). Leibniz possessed a copy of this letter and annotated it. Commenting on the very last phrase in the foregoing passage, he writes: "This agrees well enough with Boethius's definition of eternity" (Satis congruat cum definitions aeternitatis Boëtiana). See Leibniz, The Labyrinth of the Continuum: Writings on the Continuum Problem, 1672-1686, trans. and ed. Richard T. W. Arthur (New Haven, CT: Yale University Press, 200I), 106-I07.
} 
involves only possible existence, there arises the distinction between eternity and duration." ${ }^{\prime 8}$ In this early period (1663), Spinoza referred to the essence of modes as involving only possible existence, that is, being internally consistent. Later he will abandon the "involving only possible existence" terminology and instead claim that the essence of modes simply does not involve existence.

In another passage in the Cogitata Metaphysica Spinoza states the very same understanding of the nature of duration as the existence of modes in a critical note addressing certain unnamed opponents: "They have erred because they have ascribed duration to things only insofar as they judged them to be subject to continuous variation and not, as we do, insofar as their essence is distinguished from their existence." $"$ Whether modes are in some sense eternal is an important question that I will shortly address, but it is, I think, clear that God's existence is eternity, as defined in Ethics, part One, definition 8.

At this point we may wish to address a crucial problem. In propositions 2I-23 of part One of the Ethics, Spinoza lays out an outline of his theory of certain infinite entities that follow from the attributes. Scholars commonly refer to these entities as "the infinite modes," though Spinoza never used the term. These are somewhat mysterious entities that appear in Spinoza's work from a very early stage, yet, as far I can see, he never fully developed this theory. ${ }^{90}$ In the first of these three propositions he argues: "All things which follow from the absolute nature of any of God's attributes have always had to exist and be infinite, or are through the same attribute, eternal and infinite [Omnia, quae ex absoluta natura alicujus attributi Dei sequuntur, semper et infinita existere debuerunt, sive per idem attributum aeterna et infinita sunt]." 91 The immediate infinite modes, as these

$88 \mathrm{CMI}_{4}(\mathrm{G} \mathrm{I} / 244 / 13-15)$. See H. F. Hallett, Aeternitas: A Spinozistic Study (Oxford: Clarendon Press, 1930), 43-44, for a helpful discussion of this and the previous passages.

89 CM II I (G I/25I/17-19). Italics added.

90 For a detailed discussion of the infinite modes, see chapter 4 of my book Spinoza's Metaphysics.

91 Ethics, Part One, proposition 21. 
entities are commonly called, ${ }^{92}$ are described here as "eternal," but this seems to conflict with Spinoza's claims in the Letter on the Infinite that the existence of modes is duration, while eternity is the existence of substance.

Though the last point may at first look like a blunt contradiction, we can sort it out if we pay attention to the following observations. First, the phrase in Ethics, part One, proposition 2I, that asserts that infinite modes "have always had to exist" (semper ... existere debuerunt) is more consistent with an everlasting, as opposed to atemporal, understanding of eternity. ${ }^{93}$ Second, the demonstration of the aforementioned proposition does not show (or even attempt to show) that infinite modes are eternal in the strict sense of Ethics, part One, definition 8 , but only shows that these modes "cannot have a determinate duration [non potest determinatam habere durationem]." ${ }^{94}$ This obviously allows for the infinite modes to have indeterminate (or infinite) duration. Nowhere in this demonstration does Spinoza prove, or even attempt to prove, that infinite modes are atemporal. Since Spinoza was acutely aware of the distinction between endless duration and atemporality (recall my discussion of Ethics, part One. definition 8, explanation) it would be very odd for him to state one thesis and prove the other.

Third, the demonstration of Ethics, part One, proposition 21, does not at all mention Spinoza's official definition of eternity as atemporal self-necessitated existence (Ethics, part One, definition 8). Were Spinoza to argue that the immediate infinite modes are eternal in the strict sense of Ethics, part One, definition 8, the first thing he should

92 Immediate infinite modes are modes that follow directly from the nature of an attribute (see Ethics, Part One, proposition 21, demonstration). A mediate infinite mode is a mode that follows from the attribute only through the mediation of another infinite mode (see Ethics, Part One, propositions 22 and 23 ).

93 This point is also stressed by Harry Austryn Wolfson, The Philosophy of Spinoza, 2 vols. (New York: Schocken, 1969), vol. I, 377. Another commentator who qualifies the eternity of infinite modes (in Ethics, Part One, proposition 2I) unlike the eternity of substance, as mere everlastingness, is Martial Gueroult, Spinoza: Dieu (Ethique I) (Paris: Aubier, 1968), 309.

94 Ethics, part One, proposition 21, demonstration (G II/66/13). Italics added. 
do would be to appeal to the definition of eternity. ${ }^{95}$ Spinoza does mention the definition of eternity in his discussion of the infinite modes in Ethics, part One, proposition 23, demonstration, and one might be tempted to consider this evidence that the infinite modes are eternal in the strict sense of Ethics, part One, definition 8. Yet, on closer examination, we should notice that in the demonstration of proposition 23, when Spinoza invokes definition 8, he does so in order to identify eternity with "an attribute of God ... insofar as it is considered absolutely"; ${ }^{96}$ but this last characterization is clearly not true of the infinite modes, which "follow from the absolute nature of any of God's attributes" but are not this absolute nature itself.

Finally, we have clear evidence that Spinoza recognized a certain "second best" notion of eternity-eternity as everlastingness—as long as it is not applied to God (who is eternal in the strict sense of [atemporal] self-necessitated existence). Consider the following passage from the Cogitata Metaphysica:

So we pass to the second question and ask whether what has been created could have been created from eternity.

What is denoted here by the words: from eternity

To understand the question rightly, we must attend to this manner of speaking: "from eternity." For by this we wish to signify here something altogether different from what we explained previously when we spoke of God's eternity. Here we understand nothing but a duration without any beginning of duration, or a duration so great that, even if we wished to multiply it by many years, or tens of thousands of years, and this product in turn by tens of thousands, we could still never express it by any number, however large. ${ }^{97}$

95 Spinoza invokes Ethics, Part One, Definition 8, in almost all places where he proves the eternity of anything.

96 Italics added.

97 CM I Io (G I/270/17-25). 
In this passage Spinoza introduces a certain notion of eternity that is “altogether different" from God's eternity. Unlike God's eternity as self-necessitated existence, the "second best" eternity, which belongs only to created things, is identified with unlimited duration. Notice that Spinoza stresses that the "manner of speaking" that employs the expression "from eternity" (ab aeterno) indicates that what is at stake is the "second best" eternity of created things (i.e., everlastingness). In the following passage from the Short Treatise, Spinoza applies this very expression explicitly to the immediate infinite modes: "Turning now to universal Natura naturata, or those modes or creatures which immediately depend on, or have been created by God ... we say, then, that these have been created from all eternity and will remain to all eternity, immutable, a work as great as the greatness of the workman." ${ }^{98}$ We have, I believe, very strong evidence that the eternity of the infinite modes (even of the immediate infinite modes) is, unlike God's eternity, merely everlastingness. Spinoza stresses in several places that eternity truly belongs only to God.99 Arguably, in all these places he is speaking of eternity in its strict sense (of Ethics, part One, definition 8), which completely excludes duration and time.

I have just clarified one exception to Spinoza's key claim in the Letter on the Infinite that the existence of God must be explicated through eternity, while the existence of modes should be explicated as duration, that is, we have seen that the infinite modes may be described as "eternal" but only in the inferior sense of the term as mere everlastingness. But Spinoza allows for another-and bolder-exception (or apparent exception) to his dichotomy between the existence of modes and existence of substance. In several places in the Ethics, Spinoza

98 Korte Verhandeling van God de Mensch en deszelfs Welstand [Short Treatise on God, Man, and his Well-Being] I.9 (G I/48/3-9). Italics added. "From eternity to eternity" is also a translation of the Hebrew of Psalms 106:48 (Min ha-Olam ve-ad ha-Olam).

99 "And I call this infinite existence Eternity, which is to be attributed to God alone, and not to any created thing, even though its duration should be without beginning or end" (CM II I [G I/252/17-19]). See Spinoza's critique of those who think that eternity is "something beyond the divine essence" (CM II I [G I/252/II]). 
suggests that modes, even finite modes, may be adequately conceived as eternal, or sub specis aeternitatis. ${ }^{100}$ I will turn now to examine briefly two important texts in which Spinoza develops this claim.

In proposition 45 of part Two of the Ethics, Spinoza argues: "Each idea of each body, or of each singular thing which actually exists, necessarily involves an eternal and infinite essence of God.” To this proposition he adduces the following scholium:

By existence here I do not understand duration, i.e., existence insofar as it is conceived abstractly, and as a certain species of quantity. For I am speaking of the very nature of existence, which is attributed to singular things because infinitely many things follow from the eternal necessity of God's nature in infinitely many modes (see IPI I). I am speaking, I say, of the very existence of singular things insofar as they are in God. For even if each one is determined by another singular thing to exist in a certain way, still the force by which each one perseveres in existing follows from the eternal necessity of God's nature. ${ }^{101}$

For Spinoza, "singular things" (res singulares) are just the finite modes, ${ }^{102}$ but strikingly Spinoza says here that if we conceive finite modes nonabstractly-that is, as completely imbedded in the substance-we can attribute to them "the very nature of existence," which is not duration but the very eternity of God. The reason for this bold claim is simple: when we conceive modes "insofar as they are in God," that is, as completely imbedded in God, we really conceive nothing but God, and God is eternal in the strict sense of self-necessitation.

The very same point is raised again toward the end of the Ethics, where Spinoza discusses the mind's eternity. When the human mind

I0O See Ethics, Part Two, proposition 44, corollary, and Part Five, propositions 22, 30, and 31.

IOI Ethics, Part Two, proposition 45, scholium. Italics added.

IO2 See Ethics, Part Two, Definition 7: "By singular things I understand things that are finite and have a determinate existence." 
and body - two finite modes - are conceived as strictly flowing from God's essence, they take part in the very eternity of God. Thus, the 3oth proposition of part Five of the Ethics and its demonstration read:

Insofar as our Mind knows itself and the Body under a species of eternity, it necessarily has knowledge of God, and knows that it is in God and is conceived through God.

Demonstration: Eternity is the very essence of God insofar as this involves necessary existence (by ID8). To conceive things under a species of eternity, therefore, is to conceive things insofar as they are conceived through God's essence, as real beings, or insofar as through God's essence they involve existence. Hence, insofar as our Mind conceives itself and the Body under a species of eternity, it necessarily has knowledge of God, and knows, etc., q.e.d.

Notice the italicized phrase in this passage. When the human mind and body are conceived through God's essence, they thereby involve the existence which is God's essence, that is, eternity. Here again, when the mind conceives itself (and its body) as completely imbedded in God, it really conceives God, the strictly eternal being. ${ }^{103}$ Now, we can make sense of an intriguing note of Spinoza in the Letter on the Infinite. Note carefully the "insofar" clause: ${ }^{104}$ "I call the Affections of Substance Modes. Their definition, insofar as it is not the very definition of Substance, cannot involve any existence." 105 When we conceive the modes as completely imbedded in the substance, they are defined through the substance, and to that extent their definition involves existence, that is, they are eternal.

\footnotetext{
103 For further discussion of Spinoza's understanding of mind eternity, see Hallett, Aeternitas, 72-98.

I04 In a marginal note on the "insofar" clause, Leibniz asks: "So can the definition of a mode be the definition of substance in some manner?" (Labyrinth of the Continuum, 105). The demonstration of proposition 30 of Part Five of the Ethics indicates that the answer to this question is positive. Ios Spinoza, Ep. I2 (G IV/54/9-II). Italics added.
} 


\section{The Reception of Spinoza's Concept of Eternity}

\section{as Self-Necessitated Existence}

Leibniz was no fan of Spinoza. He visited Spinoza once in November I676 and was clearly impressed. ${ }^{106}$ They also shared a close friend, Baron Ehrenfried Walter von Tschirnhaus (165I-1708). But Leibniz was a Christian philosopher, and Spinoza was not. The late Leibniz was also highly suspicious of Spinoza's attempt to speak in the language of mainstream theology. Thus, in a 1707 note he remarks that Spinoza's talk about "the intellectual love of God" (amor dei intellectualis) is "nothing but soap to the masses. ${ }^{107}$ Earlier, in the 1686 Discourse on Metaphysics, Leibniz writes disparagingly about "the recent innovators who hold that the beauty of the universe and the goodness we attribute to the works of God are but the chimeras of those who conceive of God in terms of themselves." 108 Spinoza was clearly the direct target of this critique.

In light of this clear opposition to Spinoza, we might be surprised by Leibniz's unreserved adoption of Spinoza's understanding of eternity. The person whom many contemporary Europeans took to be the paragon of atheism tuned out to be the foremost expert on eternity, that is, God's essence. In 1678 Leibniz received a copy of Spinoza's Opera Posthuma, shortly after its publication. Leibniz's notes on the first few definitions of part One of the Ethics are quite critical. Yet when he comes to definition 7 ("That thing is called free which exists from the necessity of its nature alone"), ${ }^{109}$ and what is more important for this discussion, definition 8 (i.e., Spinoza's definition of eternity), Leibniz notes: "I approve of both of these definitions." 110 Along the same lines, in his New Essays on God on

I06 See my Spinoza's Metaphysics, 27-28, and 167-168. For illuminating discussions of Leibniz's friendship with Tschirnhaus, see Christia Mercer,Leibniz's Metaphysics: Its Origins and Development (Cambridge: Cambridge University Press, 2001), 408-409, and Mogens Laerke, Leibniz lecteur de Spinoza: La genese d'une opposition complexe (Paris: Honoré champion, 2008), 362-373.

107 Leibniz, Philosophical Essays, 281.

I08 Discourse on Metaphysics, section 2, in Leibniz, Philosophical Essays, 36.

I09 For a helpful discussion of Leibniz's reception of Spinoza's understanding of divine freedom, see Laerke, Leibniz lecteur de Spinoza, 834-843.

II Leibniz, Philosophical Papers and Letters, ed. and trans. Leroy E. Loemker (Dordrecht: Reidel, 1969), 197. 
Human Understanding, Theophilius, the Leibnizian interlocutor in the dialogue, rejects the view of eternity as infinite duration and identifies it instead with "the necessity of God's existence."111

A particularly interesting passage in which Leibniz allows-just like Spinoza-for eternity to have more than one sense yet insists that the more precise sense of the term is "necessity of existence" is the following: "Eternity, if it is conceived as something which is homogenous with time, will be unlimited time; but if it is conceived as the attribute of something eternal, it will be duration through an unlimited time. But the true origin and the inmost nature of eternity is the very necessity of existing, which does not of itself indicate any succession, even if it should happen that what is eternal coexists with everything. ... Eternity per se does not indicate succession." 112 Samuel Clarke, with whom Leibniz had a celebrated exchange of letters, seems also to adopt Spinoza's notion of eternity as self-necessitated existence. Thus, in his 1704 Demonstration of the Being and Attributes of God, Clarke states the Principle of Sufficient Reason and then turns to equate eternity with existence that is necessitated by the nature of the thing. "Whatever exists has a cause, a reason, a ground for its existence, a foundation on which its existence relies, a ground or reason why it does exist rather than not exists, either in the necessity of its own nature (and then it must have been of itself eternal), or in the will of some other being." 113 Later, in the very same work, Clarke notes: "The ideas of eternity and self-existence are so closely connected, that because something must of necessity be eternal independently and

\footnotetext{
II Leibniz, New Essays on Human Understanding, translated and edited by Peter Remnant and Jonathan Bennett (Cambridge: Cambridge University Press, 198I), chap. 17, sec. 18. Two recent commentators who stress the influence of Spinoza on Leibniz's concept of eternity are Michael J. Futch (Leibniz's Metaphysics of Time and Space [Berlin: Springer: 2008], 191), and Vailati (Leibniz and Clarke, 19).

II 2 Leibniz, De Summa Rerum, translated by G.H.R. Parkinson (New Haven: Yale University Press, 1992), 4I (Ak. 6.3.484). Italics added. See Leibniz, De Summa Rerum 396 (Ak. 6.3.159): "But absolute existence is eternity or necessity. From this it immediately follows that such a being does not only exist, but also exists necessarily."

II Clarke, Demonstration, 8. The curious phrase "necessity of its own nature" seems to be borrowed from proposition 16 of Part One of Spinoza's Ethics: "From the necessity of the divine nature there must follow infinitely many thing in infinitely many modes."
} 
without any outward cause, of its being, therefore it must necessarily be self-existing." 114 The view of eternity as mere everlastingness will become more and more popular throughout the eighteenth century. ${ }^{115}$ In his highly influential Metaphysics, Alexander Baumgarten (1714-1762) will mostly adopt the conception of eternity as everlastingness, though his definition of eternity will change from one edition to another, and occasionally one could still trace echoes of Spinoza's definition. ${ }^{116}$

Close to the end of the century, Moses Mendelssohn (1729-1786) will write the following in his 1785 Morgenstunden (Morning Hours), a work that is partly directed against Spinoza but still echoes his definition of eternity as self-necessitated existence: "We must admit the sort of beginning of things that is in need of no further beginning, hence, a necessary being, whose existence does not depend upon efficient causes, whose duration however is not a temporal succession without beginning but instead a timelessness, an immutable eternity that can essentially have neither beginning, nor progression, nor end.... The necessary being has, like all the necessary truths of geometry, no past and no future time.... The immutable necessary substance is at once everything that can be thought of it, and its existence knows neither increase not decrease." 117 One of Mendelssohn's major literary (and political) projects was the translation of the Bible into German. Here, when he faced the question of how to translate the Tetragrammatonthe holiest divine name, which both Maimonides and Spinoza interpreted as indicating God's self-necessitated existence, ${ }^{118}$ he settled on

\footnotetext{
II Clarke, Demonstration, 3i. It should be noted that for Clarke, unlike Spinoza, the selfnecessitated, or eternal, being is everlasting (Demonstration, 32).

II At the beginning of this chapter we encountered Newton's claim that it is more agreeable to reason to interpret God's eternity as the view condensed in the Tetragrammaton, i.e., "He that was and is and is to come." See note 8 here.

II6 Thus, in sec. 303 of the first edition, we read: "a necessary being and substance, an infinite being, is eternal." See Alexander Baumgarten, Metaphysics, trans. Courtney D. Fugate and John Hymers (London: Bloomsbury, 2013), 424 n. 358.

I17 Moses Mendelssohn, Morning Hours: Lectures on God's Existence, trans. Daniel O. Dahlstorm and Corey Dyck (Dordrecht: Springer, 2011), chap. II, pp. 67-68.

II 8 See my "Deification of Existence," 8I-86.
} 
Der Ewige (the eternal). ${ }^{119}$ Whether he had the claims of Maimonides and Spinoza in mind I will leave for the reader to decide.

\section{Abbreviations}

AT René Descartes, Oeuvres, in vols., ed. Charles Adam and Paul Tannery, new CNRS ed. (Paris: J. Vrin, 1974-86). Cited by volume and page number: "AT VII 23" stands for vol. 7, p. 23 of this edition.

Csm Cottingham, Stoothoff, and Murdoch (eds. and trans.), The Philosophical Writings of Descartes. 3 vols. (third volume edited also by A. Kenny). Cited by volume and page number: "CSM II 233 " stands for vol. 2, p. 233 of this edition.

CM Benedict Spinoza, Cogitata Metaphysica [Metaphysical thoughts], an appendix to Spinoza, Renati des Cartes Principiorum Philosophiae Pars I \& II [Descartes's Principles of Philosophy] (1663). Cited by part and chapter: "CM I Io" stands for part I, chapter io of this work.

EP. Spinoza's Letters

G Benedict Spinoza, Spinoza Opera, ed. Carl Gebhardt, 4 vols. (Heidelberg: Carl Winter, 1925). Cited by volume, page, and line number: "G II/200/I2" stands for vol. 2, p. 200, 1. I2 of this edition.

\section{Acknowledgment}

I am indebted to Stephan Schmid and Zach Gartenberg for their most helpful comments on earlier versions of this chapter.

II See Rivka Horwitz, "Mendelssohn's Commentary: The Eternal," Jewish Studies 37 (1997): 185-214. 